DR ANNIKA HERWIG (Orcid ID : 0000-0003-3048-0618)

Article type : Original Article

\title{
Alternation between short- and long photoperiod reveals hypothalamic gene regulation linked to seasonal body weight changes in Djungarian hamsters (Phodopus sungorus)
}

Jonathan H.H. Bank ${ }^{\mathrm{a}}$, Dana Wilson ${ }^{\mathrm{b}}$, Eddy Rijntjes ${ }^{\mathrm{c}}$, Perry Barrett ${ }^{\mathrm{b}}$, Annika Herwig ${ }^{\text {ad }}$,

${ }^{a}$ Zoologisches Institut, Universität Hamburg, Martin-Luther-King-Platz 3, 20146 Hamburg, Germany

${ }^{b}$ The Rowett Institute, University of Aberdeen, Foresterhill Campus, Aberdeen AB25 2ZB, United

Kingdom

'Institut für Experimentelle Endokrinologie, Charité-Universitätsmedizin Berlin, Augustenburger

Platz 1, 13353 Berlin, Germany

${ }^{d}$ corresponding author

Dr. Annika Herwig

Zoologisches Institut

Universität Hamburg

Martin-Luther-King-Platz 3

20146 Hamburg

Germany

Email: annika.herwig@uni-hamburg.de

This article has been accepted for publication and undergone full peer review but has not been through the copyediting, typesetting, pagination and proofreading process, which may lead to differences between this version and the Version of Record. Please cite this article as doi: 10.1111/jne. 12487

This article is protected by copyright. All rights reserved. 


\title{
Key words: Siberian hamster, thyroid hormone, retinoic acid, Gpr50, somatostatin
}

\begin{abstract}
Djungarian hamsters are able to reduce their body weight by more than $30 \%$ in anticipation of the winter season. This particular adaptation to extreme environmental conditions is primarily driven by a natural reduction in day length and conserved under laboratory conditions. We used this animal model to investigate hypothalamic gene expression linked to body weight regulation behind this physiological phenomenon. After an initial collective short photoperiod (SP) adaptation for 14 weeks from a preceding long photoperiod (LP), hamsters were re-exposed to LP for either six or 14 weeks, followed by a second re-exposure to SP for eight weeks. Our data showed that re-exposure to LP led to an increase in body weight. In the hypothalamus Dio2, Vimentin, Crbp1 and Grp50 expression increased, but expression of Dio3, Mct8 and Srif decreased. The changes in body weight and gene expression were reversible in most hamsters after a further re-exposure to SP following six or 14 weeks in LP. Interestingly, body weight loss was pronounced in six hamsters re-exposed to SP after 14 weeks in LP, while five hamsters did not respond to SP. In non-responding hamsters, a different gene expression pattern was manifested, with the exception of Dio2 which was reduced not only in SP re-exposed hamsters but also hamsters maintained in LP. Together these data suggest that body weight regulation seems to be tightly linked to a co-ordinated regulation of several genes in the hypothalamus including those involved in thyroid hormone metabolism.
\end{abstract}

\section{Introduction}

Seasonal mammals show a wide range of adaptations to short photoperiod in anticipation of cold winter seasons and reduced food availability. Together with quiescence of reproduction, improved winter fur and optimized thermoregulation, body weight regulation is a very important component to survive winter $(1,2)$. Djungarian hamsters (Phodopus sungorus), also known as Siberian hamsters, have been used intensively as an animal model for long-term changes in energy balance, because of their particular annual body weight cycle. They reduce body weight well in advance of the winter season and increase body weight ahead of the next reproductive period in spring $(3,4)$. These changes are primarily driven by seasonal changes in photoperiod and can be easily induced under laboratory conditions by transferring hamsters between summer-like long photoperiod (LP) or winter-like short photoperiod (SP) $(5,6)$. Internal information about day length is provided by the duration of nocturnal pineal melatonin secretion (7). Over the last decade several genes have been discovered in the hypothalamus that are potentially involved in seasonal adaptations, but their

This article is protected by copyright. All rights reserved. 
specific roles are not well understood. Much of our knowledge of genes involved in photoperiod adaptation has come from transfer of animals between static photoperiods representing LP or SP. Commonly this has been confined to a LP to a SP transition and occasionally a further transition from SP to LP. Hamsters continuously kept in SP for more than 20 weeks become insensitive to the SP signal and gradually return to their fully functional LP phenotype including body weight gain and reproductive recrudescence (8-11). This innate long-term-timing process is referred to as the photorefractory response which in nature ensures a timely start of the next reproductive season in spring. This phenomenon has also been used to investigate hypothalamic gene expression in relation to physiological adaptation $(8,12,13)$.

The hypothalamus is the centre for energy homeostasis and neuroendocrine regulator of many physiological processes and is thought to be the region of the brain which integrates altered thyroid hormone availability in response to change in day length. TSH-receptor (TSH-r) expressing tanycytes, a glial cell type in the ependymal layer of the third ventricle, is a key component in the mechanism underpinning responsiveness to day length. Tanycytes operate at the interface between the cerebrospinal fluid (CSF) and neurons of the hypothalamus $(14,15)$ and change in structure (vimentin) as well as function in response to seasonal change in photoperiod $(16,17)$.

The contemporary view for the involvement of tanycytes in the mechanism of physiological adaptation centres around responding to thyrotropin (TSH) produced by melatonin responsive cells in the pars tuberalis (PT) (18). In LP production of TSH in the PT is high, which leads to an increased deiodinase type 2 (DIO2) expression in tanycytes $(18,19)$. DIO2 is an enzyme involved in thyroid hormone metabolism and there is a large body of evidence to show that thyroid hormone availability specifically in the hypothalamus underpins the mechanism driving seasonal adaptations $(8,18-21)$. Thyroid hormone availability in the hypothalamus depends on thyroid hormone transport by specific transporters e.g. monocarboxylate transporter 8 (MCT8), as well as the activity of deiodinase enzymes. Whereas DIO2 converts thyroxine by phenolic ring deiodination $\left(T_{4}\right)$ to biologically active $3,3^{\prime}, 5$-triiodothyronine $\left(\mathrm{T}_{3}\right)$, type 3 deiodinase (DIO3) acts as counterpart and inactivates $T 3$ by tyrosyl ring deiodination to 3,3'-diiodothyronine $\left(T_{2}\right)(22-24)$. Both, transporter and enzymes are expressed in tanycytes in Djungarian hamsters and are regulated in a photoperiod dependent manner, Dio2 being high in LP and low in SP and Dio3 absent in LP, but transiently expressed on exposure to SP. Several studies have suggested that a low $T_{3}$ concentration in the hypothalamus, generated by low Dio2 expression and high Dio3 expression, is required for body mass reduction $(8,20,21,25)$.

This article is protected by copyright. All rights reserved. 
In addition to genes involved in the thyroid hormone signalling pathway, several other hypothalamic genes are regulated by photoperiod and have been linked to seasonal adaptations (26-28). Cellular retinol-binding protein 1 (CRBP1), that is expressed in tanycytes, is a transport protein for retinol (vitamin A) and involved in the pathway for synthesizing retinoic acid (29). Another protein expressed in the ependymal layer is GPR50, an orphan G-protein-coupled receptor, which despite its homology to melatonin receptors, does not bind melatonin and has been suggested to play a role in sensing components of metabolic homeostasis in the CSF $(30,31)$. Somatostatin (SRIF) is produced in the arcuate nucleus (ARC) and periventricular nucleus of the hypothalamus and plays a role in the regulation of the growth axis, for which there is evidence that this axis contributes to the seasonal body weight cycle of Djungarian hamsters (8, 32-34).

The aim of this study was to develop a better understanding of photo-responsive genes by investigating their transcriptional plasticity to multiple directional changes between photoperiods. Hamsters adapted to a static SP for more than ten weeks, but then re-exposed to LP have shown that physiological adaptations revert to LP phenotype within a period of six weeks $(33,35)$. Prior to the onset of changes in physiology the expression of most genes revert back to LP expression levels, with Dio2 expressed to a greater level than in hamsters continuously kept in $\operatorname{LP}(8,12)$.

From a life history perspective, at least in the laboratory Djungarian hamsters may survive two winter seasons, particularly those born after the summer solstice which adapt to SP physiology soon after birth $(9,34,36)$. Therefore the potential for survival for more than one winter season, whether in a laboratory situation or their natural environment, needs to be reflected in an ability to respond to seasonal photoperiod cues to maximize the chances of survival and provide for continuation of the species. Although hypothalamic gene expression studies have been performed on LP to SP transition and a subsequent SP to LP transition, there is no further information on the plasticity of Dio2 and other critical components of the hypothalamic thyroid hormone pathway in response to a further directional change back to SP following LP exposure. Previously it has been found that responsiveness to melatonin or SP in photorefractory hamsters is only re-established after a return to LP for a minimum of ten weeks in LP (37-39). Based on this response, we hypothesised that a multiple transition model may provide additional insight into the plasticity of hypothalamic gene expression and physiological adaptions. In particular, hamsters transferred from LP to SP for a second time may not be responsive to SP after a short adaptation to LP. Investigating the responsiveness to multiple photoperiod transitions may help in understanding the plasticity of the

This article is protected by copyright. All rights reserved. 
hypothalamic thyroid hormone signalling and the importance of neuroendocrine pathways following photorefractory physiological recrudescence.

\section{Material and Methods}

\section{Animals and experimental procedure}

All experiments and procedures were approved by the local animal welfare authorities (Hamburg, Germany). Fifty-two Djungarian hamsters (Phodopus sungorus) of both sexes were bred and raised under artificial long photoperiod (LP; $16 \mathrm{~h}$ light : $8 \mathrm{~h}$ dark). After weaning, hamsters were singly housed in Makrolon type III cages with food and water ad libitum at an ambient temperature $\left(T_{a}\right)$ of $21 \pm 1{ }^{\circ} \mathrm{C}$. The experimental protocol is outlined in Figure 1. All animals were culled between Zeitgeber time (ZT) 4-5 in their respective photoperiods. At an age of 3-4 month (=week 0) a cohort of six hamsters $\left(\mathrm{LP}_{0}\right)$ was euthanized by $\mathrm{CO}_{2}$ inhalation and decapitation under $\mathrm{LP}$ conditions. The remaining 46 adult hamsters were transferred to an artificial short photoperiod (SP, $8 \mathrm{~h}$ light : $16 \mathrm{~h}$ dark). Hamsters were weighed once a week. After 14 weeks in SP a group of six hamsters $\left(\mathrm{SP}_{14}\right)$ was sacrificed and 40 hamsters were transferred back to LP. After six weeks in LP a further cohort of six hamsters $\left(\mathrm{SP}_{14} \mathrm{LP}_{6}\right)$ was killed. At this time point a group of six hamsters was switched back to SP for a second time and culled after eight weeks under SP conditions $\left(\mathrm{SP}_{14} \mathrm{LP}_{6} \mathrm{SP}_{8}\right)$. Six hamsters kept under $\mathrm{LP}$ for 14 weeks $\left(\mathrm{SP}_{14} \mathrm{LP}_{14}\right)$ after the first switch from SP were culled together with the $\mathrm{SP}_{14} \mathrm{LP}_{6} \mathrm{SP}_{8}$ group. The remaining 22 hamsters were split into two groups. Eleven hamsters stayed in LP for another eight weeks $\left(\mathrm{SP}_{14} \mathrm{LP}_{22}\right)$ and eleven hamsters were switched back to SP for also eight weeks $\left(\mathrm{SP}_{14} \mathrm{LP}_{14} \mathrm{SP}_{8}\right)$. Those hamsters were sacrificed at the end of the experiment. Blood of all hamsters was collected, serum extracted and total $T_{4}\left(t T_{4}\right)$ and total $T_{3}\left(t T_{3}\right)$ serum concentrations were analysed by radio-immuno assays (RIA) as described before (40). The brains were removed, immediately frozen on dry ice and stored at $-80^{\circ} \mathrm{C}$ until required for in situ hybridization.

\section{Radioactive in situ hybridisation}

In situ hybridization was used to quantify expression of Dio2, Dio3, Mct8, Tsh-r, Crbp1, Gpr50 and Vimentin mRNA along the third ventricle of the hypothalamus and quantification of Srif was restricted to the ARC region within the hypothalamus. The hypothalamic region of interest was between bregma -1.70 and $-2.54 \mathrm{~mm}$ according to the Mouse Brain Atlas of Franklin \& Paxinos ( $3^{\text {rd }}$ ed., 2008). Frozen brains were cut with a cryostat into $16 \mu \mathrm{m}$ coronal sections, mounted onto polysine-coated slides and stored at $-80^{\circ} \mathrm{C}$ until needed.

This article is protected by copyright. All rights reserved. 
For in situ hybridization, brain sections were fixed in 4\% paraformaldehyde, washed with $0.1 \mathrm{M} \mathrm{PBS}$, incubated in $0.1 \mathrm{M}$ triethanolamine $(\mathrm{pH} 8)$ and acetylated with $0.25 \%$ acetic anhydride. Slides were washed again with 0.1 M PBS and subsequently dehydrated using an ascending ethanol series followed by vacuum drying. Riboprobes were synthesized as previously described from DNA fragments for Dio2, Dio3, Mct8, Tsh-r, Crbp1, Gpr50, Vimentin and Srif, using ${ }^{35}$ S-UTP with SP6 or T7 polymerases as appropriate $(8,21,25,26,28,41)$. $70 \mu$ l hybridization mixture (formamide, $0.3 \mathrm{M}$ $\mathrm{NaCl}, 10 \mathrm{mM}$ Tris-HCL (pH 8), $1 \mathrm{mM}$ EDTA, 0.05\% transfer RNA, $10 \mathrm{mM}$ dithiothreitol,0.02\% Ficoll, $0.02 \%$ polyvinylpyrrolidone, $0.02 \% \mathrm{BSA}$, and $10 \%$ dextran sulphate) containing the appropriate radioactive probes (ca. $10^{6} \mathrm{cpm}$ ) was applied per glass slide and sealed with DPX Mountant. Hybridization was carried out over night at $58^{\circ} \mathrm{C}$. After hybridization, slides were washed in $4 \mathrm{x}$ SSC (Saline-Sodium Citrate), incubated with RNase A solution at $37^{\circ} \mathrm{C}$ for 30 minutes and washed in SSC solutions with decreasing concentrations $(2 x$ to $0.1 x)$. Finally slides were dehydrated using an ascending ethanol series and air dried before exposed to Kodak BioMax MR Films (Sigma-Aldrich Company Ltd., Poole, Dorset, UK). Autoradiographic films were developed after 18-20h (Srif, Vimentin), 5 days (Mct8), 6 days (Gpr50), 7 days (Crbp1, Tsh-r) or 14 days (Dio2, Dio3). Autoradiographic films were scanned at $300 \mathrm{dpi}$ and analysed using ImageJ $1.47 \mathrm{v}$ software. Integrated optical density (IOD) was obtained in two to three consecutive sections per animal by reference to a standard curve $[y=a+b * \ln (x-c)]$ generated from $a{ }^{14} \mathrm{C}$ microscale, was measured. Values were averaged for each animal. Relative gene expression was calculated by defining $\mathrm{SP}_{14}$ as 100\% for Dio2, Dio3, Mct8 and Srif and $\mathrm{LP}_{0}$ as 100\% for Crbp1, Tsh-r, Gpr50 and Vimentin.

\section{Statistical analysis}

Changes in body weight and differences between groups were tested by Two-way repeated measures ANOVA and Tukey post-hoc test. Differences in gene expression and serum concentrations between groups were analysed by student's t-test (t-test, parametric) or Mann-Whitney-U test (Utest, non-parametric) as appropriate. P-Values ${ }^{*}<0.05, * *<0.01, * * *<0.001$ were considered as significant. Statistical analyses were performed with SigmaPlot ${ }^{\mathrm{TM}} 12$ (Systat Software Inc).

\section{Results}

\section{Body weight}

Hamsters started with an initial average body weight of $34.3 \pm 4.8 \mathrm{~g}$. During 14 weeks in SP the six groups of hamsters which were transferred to SP showed a body weight reduction of $-8.8 \pm 4.7 \mathrm{~g}$ that reached significance from week 6 (Figure 2A, B, ANOVA $p<0.05$ ). The five groups switched back

This article is protected by copyright. All rights reserved. 
to LP increased their body weight by $7.1 \pm 3.3 \mathrm{~g}$ after six weeks. The increase reached significance four weeks after the switch to LP (ANOVA $p<0.05$ ). The groups which experienced extended LP reached a body weight plateau after 12 weeks in LP and had increased their body weight after 14 weeks by $18.1 \pm 6.1 \mathrm{~g}\left(\mathrm{SP}_{14} \mathrm{LP}_{14}\right)$ and by $18.9 \pm 5.9 \mathrm{~g}$ after 22 weeks $\left(\mathrm{SP}_{14} \mathrm{LP}_{22}\right)$.

Hamsters switched back to SP for a second time after six weeks in $L P\left(\mathrm{SP}_{14} \mathrm{LP}_{6} \mathrm{SP}_{8}\right)$ stopped increasing body weight $(-2.8 \pm 2.07$, ANOVA $p=0.11)$ and had a significantly lower body weight compared to the corresponding age matched $\mathrm{SP}_{14} \mathrm{LP}_{14}$ group (ANOVA $\mathrm{p}<0.05$ ). However the range of responsiveness to the second SP varied from no weight loss to $21.6 \%$ in one hamster, which is in contrast to weight loss after the first exposure to $\mathrm{SP}$ where all $\mathrm{SP}_{14} \mathrm{LP}_{6} \mathrm{SP}_{8}$ animals lost $12 \%$ or more during eight weeks of SP exposure (Figure 2A, Supplementary Figure 1B).

Of the hamsters re-exposed to SP after 14 weeks in $\mathrm{LP}\left(\mathrm{SP}_{14} \mathrm{LP}_{14} \mathrm{SP}_{8}\right)$, there was an apparent division in the body weight responsiveness of some hamsters compared to others. We therefore applied a criteria of SP responsiveness to this group which was a body weight loss of $10 \%$ or greater from peak value by seven weeks into SP (Figure 4A). This criterion would exclude the classification of hamsters as responsive due to natural variability in body hamster weight which would include variability in food stored in cheek pouches. After the initial exposure to SP from LP, all hamsters in this $\mathrm{SP}_{14} \mathrm{LP}_{14} \mathrm{SP}_{8}$ group had a body weight loss of $14 \%$ or more within seven weeks and continued to lose body weight with an average weight loss of $26.2 \% \pm 6.6 \%$ after 14 weeks SP exposure and were therefore clearly all photoresponsive hamsters in the first transition from LP to SP. However in a second re-exposure to SP, six hamsters reduced their body weight by $6.5 \pm 4.4 \mathrm{~g}(15.1 \% \pm 3.1 \%$, ANOVA $p<0.05)$, whereas five hamsters on average did not lose body weight within eight weeks of SP exposure (Figure $4 \mathrm{~A},-0.7 \pm 1.3 \mathrm{~g},-2.7 \% \pm 2.5 \%$,) with no significant difference between the nonresponding hamsters and the corresponding age matched $\mathrm{SP}_{14} \mathrm{LP}_{22}$ group.

\section{Serum thyroid hormone concentrations}

No significant differences in serum thyroid hormone levels were found between the groups (Table 1). Hamsters kept at $L P$ for six weeks after switched back from $S P\left(S_{14} L P_{6}\right)$ showed a trend towards an increase in $\mathrm{tT}_{4}$ compared to hamsters kept in $\mathrm{SP}$ for 14 weeks $\left(\mathrm{SP}_{14} \mathrm{LP}_{14} \mathrm{VS}_{\mathrm{SP}} \mathrm{SP}_{14} \mathrm{LP}_{6}, \mathrm{t}\right.$-test $\left.\mathrm{p}=0.057\right)$. Serum thyroid hormone concentrations within the group $\mathrm{SP}_{14} \mathrm{LP}_{14} \mathrm{SP}_{8}$ revealed no differences between hamsters which lost body weight and stable body weight. The $\mathrm{SP}_{14} \mathrm{LP}_{14} \mathrm{SP}_{8}$ group showed a statistical trend towards higher $\mathrm{tT}_{4}$ concentrations compared to the corresponding $\mathrm{SP}_{14} \mathrm{LP}_{22}$ group ( $\mathrm{t}$ test $p=0.077$ ).

This article is protected by copyright. All rights reserved. 
Hypothalamic gene expression

Dio2 expression was lower in hamsters that had experienced only $L P$ as compared to $\mathrm{SP}_{14}\left(\mathrm{LP}_{0} \mathrm{VS}\right.$ $\mathrm{SP}_{14}, 61 \pm 11 \%$, t-test $\mathrm{p}=0.03$, Figure $3 \mathrm{~A}$ ). After re-exposure from SP to LP Dio2 expression was increased by more than 6 -fold after six weeks $\left(\mathrm{SP}_{14} \mathrm{LP}_{6} \mathrm{Vs} \mathrm{SP}_{14}, 630 \pm 81 \%\right.$, U-test $\left.\mathrm{p}=0.002\right)$, before it declined in the following eight weeks, but with still elevated mRNA concentrations after 14 weeks in $\mathrm{LP}\left(\mathrm{SP}_{14} \mathrm{LP}_{14} \mathrm{VS} \mathrm{SP}_{14}, 208 \pm 17 \%\right.$, t-test $\left.\mathrm{p}<0.001\right)$. Dio2 expression was back to original $\mathrm{LP}_{0} \mathrm{mRNA}$ levels and below $\mathrm{SP}_{14}$ values after 22 weeks in $\mathrm{LP}\left(\mathrm{SP}_{14} \mathrm{LP}_{22}\right.$ vs $\mathrm{SP}_{14}, 44 \pm 3 \%$, t-test $\left.\mathrm{p}<0.001\right)$. Hamsters transferred to SP for a second time for eight weeks after six weeks in $\mathrm{LP}\left(\mathrm{SP}_{14} \mathrm{LP}_{6} \mathrm{SP}_{8}\right)$ had lower Dio2 levels compared to $\mathrm{SP}_{14}\left(\mathrm{SP}_{14} \mathrm{LP}_{6} \mathrm{SP}_{8}\right.$ vs $\mathrm{SP}_{14}, 56 \pm 5 \%$, t-test $\left.\mathrm{p}=0.002\right)$. Lower Dio2 expression than the $\mathrm{SP}_{14}$ cohort was also observed in hamsters re-exposed to SP for eight weeks after 14 weeks in LP $\left(\mathrm{SP}_{14} \mathrm{LP}_{14} \mathrm{SP}_{8}\right)$, but only in hamsters that had reduced their body weight $\left(\mathrm{SP}_{14} \mathrm{LP}_{14} \mathrm{SP}_{8}\right.$ body weight loss vs $\mathrm{SP}_{14}, 50 \pm 8 \%$, t-test $\mathrm{p}=0.003$ ). Hamsters of $\mathrm{SP}_{14} \mathrm{LP}_{14} \mathrm{SP}_{8}$ that did not reduce body weight on $\mathrm{SP}$ reexposure, showed Dio2 expression similar to $\mathrm{SP}_{14}\left(\mathrm{SP}_{14} \mathrm{LP}_{14} \mathrm{SP}_{8}\right.$ constant body weight vs $\mathrm{SP}_{14}, 73 \pm$ $13 \%$, t-test $\mathrm{p}=0.17$, Figure $3 \mathrm{~A}, 4 \mathrm{~B})$. Although marginally higher, Dio2 expression in hamsters that did not lose body weight was not statistically different from body weight responders $\left(\mathrm{SP}_{14} \mathrm{LP}_{14} \mathrm{SP}_{8}\right.$ body weight loss vs $\mathrm{SP}_{14} \mathrm{LP}_{14} \mathrm{SP}_{8}$ no body weight loss, $68 \pm 11 \%$, t-test $\mathrm{p}=0.2$, Figure $3 \mathrm{~A}, 4 \mathrm{~B}$ ).

Deiodinase 3 (Dio3)

Dio3 was not expressed in LP, but at different levels in all hamsters culled during SP (Figure 3B). The $\mathrm{SP}_{14} \mathrm{LP}_{6} \mathrm{SP}_{8}$ group was not significantly different from $\mathrm{SP}_{14}\left(\mathrm{SP}_{14} \mathrm{LP}_{6} \mathrm{SP}_{8}\right.$ vs $\mathrm{SP}_{14}, 54 \pm 28 \%$, t-test $\mathrm{p}=0.184$ ). This is due to the large variability in this group. Four hamsters showed no Dio3 expression comparable to LP animals, whereas two hamsters showed increased gene expression comparable to $\mathrm{SP}_{14}$ values. In the $\mathrm{SP}_{14} \mathrm{LP}_{14} \mathrm{SP}_{8}$ group all hamsters with reduced body weight had increased Dio3 expression ( $\mathrm{SP}_{14} \mathrm{LP}_{14} \mathrm{SP}_{8}$ body weight loss vs $\mathrm{SP}_{14}, 184 \pm 30 \%$, t-test $\mathrm{p}=0.04$, Figure 3B, 4B), and Dio3 was only partially induced in hamsters with constant body weight $\left(\mathrm{SP}_{14} \mathrm{LP}_{14} \mathrm{SP}_{8}\right.$ constant body weight vs $\mathrm{SP}_{14}, 46 \pm 44 \%$, U-test $\mathrm{p}=0.13$, Figure $\left.3 \mathrm{~B}, 4 \mathrm{~B}\right)$. Only one hamster showed increased Dio3 expression, whereas the other four animals had very low Dio3 mRNA concentrations (Figure 4B). Within the $\mathrm{SP}_{14} \mathrm{LP}_{14} \mathrm{SP}_{8}$ group Dio3 expression was significantly different between hamsters losing body weight and those maintaining constant body weight $\left(\mathrm{SP}_{14} \mathrm{LP}_{14} \mathrm{SP}_{8}\right.$ constant body weight vs $\mathrm{SP}_{14} \mathrm{LP}_{14} \mathrm{SP}_{8}$ body weight loss, $25 \pm 21 \%$, U-test $\mathrm{p}=0.03$ ).

This article is protected by copyright. All rights reserved. 
Monocarboxylate transporter 8 (Mct8)

Mct8 expression (Figure 5A) did not differ after 14 weeks in SP $\left(\mathrm{SP}_{14}\right)$ from $\mathrm{LP}_{0}\left(\mathrm{LP}_{0} \mathrm{vs} \mathrm{SP}_{14}, 87 \pm 8 \%\right.$, $\mathrm{t}$ test $\mathrm{p}=0.22$ ). After re-exposure from $S P$ to $L P, M c t 8$ expression was reduced in all $L P$ groups. Six weeks after re-exposure $\left(\mathrm{SP}_{14} \mathrm{LP}_{6}\right.$ vs $\mathrm{SP}_{14}, 43 \pm 5 \%$, t-test $\left.\mathrm{p}<0.001\right), 14$ weeks after re-exposure $\left(\mathrm{SP}_{14} \mathrm{LP}_{14}\right.$ Vs $\mathrm{SP}_{14}, 67 \pm 9 \%$, t-test $\left.\mathrm{p}=0.009\right)$ and 22 weeks after re-exposure $\left(\mathrm{SP}_{14} \mathrm{LP}_{22}\right.$ Vs $\mathrm{SP}_{14}, 51 \pm 12 \%$, t-test $\mathrm{p}<0.001)$ Mct8 expression was significantly lower. Hamsters of $\mathrm{SP}_{14} \mathrm{LP}_{6} \mathrm{SP}_{8}$ had higher Mct8 expression as compared to the parallel $\mathrm{SP}_{14} \mathrm{LP}_{14}$ group $\left(\mathrm{SP}_{14} \mathrm{LP}_{14}\right.$ vs $\mathrm{SP}_{14} \mathrm{LP}_{6} \mathrm{SP}_{8}, 177 \pm 15 \%$, t-test $\mathrm{p}=0.003)$ which was similar to the $\mathrm{SP}_{14}$ group $\left(\mathrm{SP}_{14} \mathrm{LP}_{6} \mathrm{SP}_{8}\right.$ vs $\mathrm{SP}_{14}, 119 \pm 10 \%$, t-test $\left.\mathrm{p}=0.19\right)$. The $\mathrm{SP}_{14} \mathrm{LP}_{14} \mathrm{SP}_{8}$ group showed an interesting pattern. In hamsters with body weight loss, gene expression of Mct8 was higher than in $\mathrm{SP}_{14}$ animals $\left(\mathrm{SP}_{14} \mathrm{LP}_{14} \mathrm{SP}_{8}\right.$ body weight loss vs $\mathrm{SP}_{14}, 129 \pm 10 \%$, t-test

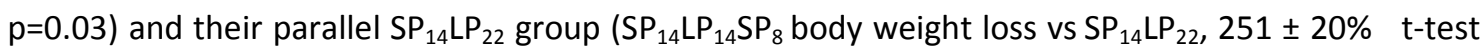
$\mathrm{p}<0.001)$. However, hamsters of $\mathrm{SP}_{14} \mathrm{LP}_{14} \mathrm{SP}_{8}$ maintaining constant body weight had unchanged Mct8 expression compared to $\mathrm{SP}_{14}\left(\mathrm{SP}_{14} \mathrm{LP}_{14} \mathrm{SP}_{8}\right.$ constant body weight vs $\mathrm{SP}_{14}, 86 \pm 19 \%$, U-test $\left.\mathrm{p}=0.6\right)$, but expression was lower compared to the hamsters with lost body weight within the $\mathrm{SP}_{14} \mathrm{LP}_{14} \mathrm{SP}_{8}$ group $\left(\mathrm{SP}_{14} \mathrm{LP}_{14} \mathrm{SP}_{8}\right.$ constant body weight vs $\mathrm{SP}_{14} \mathrm{LP}_{14} \mathrm{SP}_{8}$ body weight loss, $66 \pm 12 \%$, t-test $\left.\mathrm{p}=0.04\right)$.

\section{Thyrotropin receptor (Tsh-r)}

In situ hybridization revealed no generalised response caused by directional changes in photoperiod of Tsh-r expression (data not shown). The only significant difference (t-test $p=0.01$ ) appeared between $\mathrm{SP}_{14} \mathrm{LP}_{14}(116 \pm 7 \%)$ and $\mathrm{SP}_{14} \mathrm{LP}_{6} \mathrm{SP}_{8}(85 \pm 7 \%)$.

\section{Vimentin}

Vimentin mRNA expression (Figure 5B) was decreased after 14 weeks in $\mathrm{SP}\left(\mathrm{SP}_{14}\right.$ vs $\mathrm{LP}_{0}, 37 \pm 2 \%$, $\mathrm{t}$ test $p<0.001)$. Six weeks after re-exposure from $\mathrm{SP}_{14}$ to $L P\left(\mathrm{SP}_{14} \mathrm{SP}_{6}\right)$ Vimentin expression was increased $\left(\mathrm{SP}_{14} \mathrm{LP}_{6}\right.$ Vs $\mathrm{SP}_{14}, 203 \pm 13 \%$, U-test $\left.\mathrm{p}=0.002\right)$ and continued to increase reaching $100 \pm 6 \%$ of original $L P$ values after eight more weeks in $L P\left(S_{14} L_{14} V s P_{14}, 269 \pm 15 \%\right.$, U-test $\left.p=0.002\right)$. Hamsters from group $\mathrm{SP}_{14} \mathrm{LP}_{6} \mathrm{SP}_{8}\left(\mathrm{SP}_{14} \mathrm{LP}_{6} \mathrm{SP}_{8}\right.$ vs $\mathrm{SP}_{14} \mathrm{LP} \mathrm{P}_{14}, 50 \pm 7 \%$, t-test $\left.\mathrm{p}=0.002\right)$ and $\mathrm{SP}_{14} \mathrm{LP}_{14} \mathrm{SP}_{8}$ hamsters with reduced body weight $\left(\mathrm{SP}_{14} \mathrm{LP}_{14} \mathrm{SP}_{8}\right.$ body weight loss vs $\mathrm{SP}_{14} \mathrm{LP}_{22}, 60 \pm 14 \%$, $\mathrm{t}$-test $\mathrm{p}=0.03$ ) had lower Vimentin expression as compared to their parallel control LP groups. $\mathrm{SP}_{14} \mathrm{LP}_{14} \mathrm{SP}_{8}$ hamsters maintaining constant body weight, had levels comparable to their $\mathrm{LP}_{22}$ control animals $\left(\mathrm{SP}_{14} \mathrm{LP}_{14} \mathrm{SP}_{8}\right.$ constant body weight vs $\mathrm{SP}_{14} \mathrm{LP}_{22}, 105 \pm 15 \%$, t-test $\left.\mathrm{p}=0.8\right)$. Vimentin expression was significantly lower in hamsters losing body weight than in hamsters maintaining constant body weight ( $\mathrm{SP}_{14} \mathrm{LP}_{14} \mathrm{SP}_{8}$ body weight loss vs $\mathrm{SP}_{14} \mathrm{LP}_{14} \mathrm{SP}_{8}$ constant body weight, $58 \pm 7 \%$, t-test $\mathrm{p}=0.003$ )

This article is protected by copyright. All rights reserved. 


\section{G protein-coupled receptor 50 (Gpr50)}

Abundance of Gpr50 mRNA (Figure 5C) showed clear differences between hamsters kept at LP or SP. After 14 weeks in SP (SP $\left.{ }_{14}\right)$ Gpr50 expression was significantly reduced ( $\mathrm{SP}_{14} \mathrm{Vs} \mathrm{LP}_{0}, 22 \pm 1 \%$, U-test $p=0.002)$. Expression was partially restored six weeks after re-exposure to $L P\left(S P_{14} L P_{6} v s L P_{0}, 47 \pm 6 \%\right.$, t-test $p=0.001)$ and regained original $L P_{0}$ expression after 14 weeks in $L P\left(S P_{14} L P_{14} V s L P_{0}, 103 \pm 9 \%\right)$.

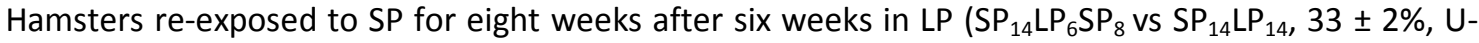
test $\mathrm{p}=0.002)$ or 14 weeks in $\mathrm{LP}\left(\mathrm{SP}_{14} \mathrm{LP}_{14} \mathrm{SP}_{8}\right.$ body weight loss vs $\mathrm{SP}_{14} \mathrm{LP}_{22}, 32 \pm 3 \%$, U-test $\left.\mathrm{p}=0.001\right)$ had decreased Gpr50 expression relative to their LP controls, except hamsters, that did not reduce body weight $\left(\mathrm{SP}_{14} \mathrm{LP}_{14} \mathrm{SP}_{8}\right.$ constant body weight vs $\mathrm{SP}_{14} \mathrm{LP}_{22}, 74 \pm 11 \%$, t-test $\left.\mathrm{p}=0.066\right)$. In the $\mathrm{SP}_{14} \mathrm{LP}_{14} \mathrm{SP}_{8}$ group Gpr50 expression was lower in hamsters showing a body weight response than in those showing no response to $\mathrm{SP}$ exposure. $\left(\mathrm{SP}_{14} \mathrm{LP}_{14} \mathrm{SP}_{8}\right.$ body weight loss vs $\mathrm{SP}_{14} \mathrm{LP}_{14} \mathrm{SP}_{8}$ constant body weight, $44 \pm 5 \%$, U-test $p=0.004)$.

Cellular Retinol-Binding Protein 1 (Crbp1)

Crbp1 expression was clearly reduced after 14 weeks in $\mathrm{SP}\left(\mathrm{SP}_{14}\right)$ relative to $\mathrm{LP}_{0}\left(\mathrm{SP}_{14} \mathrm{vs} \mathrm{LP}_{0}, 11 \pm 3 \%\right.$, U-test $p=0.002$ ) and increased again after re-exposure to LP (Figure 5D). After six weeks in LP $\left(\mathrm{SP}_{14} \mathrm{LP} \mathrm{P}_{6}\right)$ the mRNA concentration increased to $64 \pm 14 \%$ and was not significantly different from $\mathrm{LP}_{0}$ $\left(\mathrm{SP}_{14} L \mathrm{~L}_{6}\right.$ vs $L \mathrm{P}_{0}$, t-test $\left.\mathrm{p}=0.15\right)$. In the $\mathrm{SP}_{14} \mathrm{LP}_{6} \mathrm{SP}_{8}$ group, gene expression returned to $\mathrm{SP}_{14}$ levels and was significantly lower than its matched $L P$ group $\left(\mathrm{SP}_{14} \mathrm{LP}_{6} \mathrm{SP}_{8}\right.$ vs $\mathrm{SP}_{14} \mathrm{LP}_{14}, 20 \pm 4 \%$, $t$-test $\left.\mathrm{p}=0.002\right)$. Both $\mathrm{SP}_{14} \mathrm{LP}_{14} \mathrm{SP}_{8}$ groups had higher Crbp1 expression than the $\mathrm{SP}_{14}$ group $\left(\mathrm{SP}_{14} \mathrm{LP}_{14} \mathrm{SP}_{8}\right.$ body weight loss vs $\mathrm{SP}_{14}, 260 \pm 65 \%$, t-test $\mathrm{p}=0.049 ; \mathrm{SP}_{14} \mathrm{LP}_{14} \mathrm{SP}_{8}$ no body weight loss vs $\mathrm{SP}_{14}, 436 \pm 83 \%$, t-test $p=0.004)$. $\mathrm{SP}_{14} \mathrm{LP}_{14} \mathrm{SP}_{8}$ hamsters had significantly lower mRNA levels than the $\mathrm{SP}_{14} \mathrm{LP}_{22}$ animals, if they had lost body weight ( $\mathrm{SP}_{14} \mathrm{LP}_{14} \mathrm{SP}_{8}$ body weight loss vs $\mathrm{SP}_{14} \mathrm{LP}_{22}, 38 \pm 9 \%$, t-test $\mathrm{p}=0.002$ ), but $\mathrm{Crbp} 1$ expression was not different if body weight remained constant $\left(\mathrm{SP}_{14} \mathrm{LP}_{14} \mathrm{SP}_{8}\right.$ constant body weight vs $\mathrm{SP}_{14} \mathrm{LP}_{22}, 63 \pm 12 \%$, t-test $\left.\mathrm{p}=0.08\right)$.

\section{Somatostatin/somatotropin release inhibiting factor (Srif)}

Somatostatin was weakly expressed in all LP groups (Figure 5E). After 14 weeks in $\mathrm{SP}_{14}$ somatostatin expression was approximately 7-fold increased relative to $\mathrm{LP}_{0}\left(\mathrm{SP}_{14}\right.$ Vs $\mathrm{LP}_{0}, 683 \pm 78 \%$, U-test $p=0.002$ ). The re-exposure from SP to $L P$, caused a decrease in Srif expression to $7 \pm 1 \%$ within six weeks ( $\mathrm{SP}_{14} \mathrm{LP}_{6}$ Vs $\mathrm{SP}_{14}, \mathrm{U}$-test $\left.\mathrm{p}=0.002\right)$. Hamsters re-exposed to $\mathrm{SP}$ for a further eight weeks, after six weeks in $\mathrm{LP}\left(\mathrm{SP}_{14} \mathrm{LP}_{6} \mathrm{SP}_{8}\right)$, showed a partial reverse of Srif expression to $36 \pm 3 \%\left(\mathrm{SP}_{14} \mathrm{LP}_{6} \mathrm{SP}_{8}\right.$ vs $\mathrm{SP}_{14}$, U-test $\mathrm{p}=0.002$ ), in contrast to a low expression in hamsters maintained in continuing $\mathrm{LP}$ $\left(\mathrm{SP}_{14} \mathrm{LP}_{14}\right.$ vs $\mathrm{SP}_{14}, 13 \% \pm 2 \%$, t-test $\left.\mathrm{p}=0.002\right)$. After 14 weeks in $\mathrm{LP}$ and another eight weeks in $\mathrm{SP}$

This article is protected by copyright. All rights reserved. 
$\left(\mathrm{SP}_{14} \mathrm{LP}_{14} \mathrm{SP}_{8}\right)$ Srif only showed increased expression in hamsters that reduced body weight compared to the matching $\mathrm{LP}$ group ( $\mathrm{SP}_{14} \mathrm{LP}_{14} \mathrm{SP}_{8}$ body weight loss vs $\mathrm{SP}_{14} \mathrm{LP}_{22}, 378 \pm 36 \%$, U-test $\left.\mathrm{p}<0.001\right)$. This partial increase was significantly lower as compared to $\mathrm{SP}_{14}\left(\mathrm{SP}_{14} \mathrm{LP}_{14} \mathrm{SP}_{8}\right.$ body weight loss vs $\mathrm{SP}_{14}, 60$ $\pm 6 \%$, U-test $p=0.01)$. Hamsters that did not respond to SP re-exposure maintained low Srif expression which was comparable to hamsters maintained in $L P$ for 22 weeks $\left(\mathrm{SP}_{14} \mathrm{LP}_{14} \mathrm{SP}_{8}\right.$ constant body weight vs $\mathrm{SP}_{14}, 28 \pm 7 \%$, t-test $\left.\mathrm{p}<0.001\right)$. Srif expression was significantly higher in hamsters of $\mathrm{SP}_{14} \mathrm{LP}_{14} \mathrm{SP}_{8}$ that lost body weight compared to those maintaining body weight $\left(\mathrm{SP}_{14} \mathrm{LP}_{14} \mathrm{SP}_{8}\right.$ body weight loss vs $\mathrm{SP}_{14} \mathrm{LP}_{14} \mathrm{SP}_{8}$ constant body weight, $217 \pm 20 \%$, t-test $\mathrm{p}=0.004$ )

\section{Discussion}

\section{Body weight}

Hamsters reduced their body weight during an exposure to SP for 14 weeks. As expected body weight increased after re-exposure to $L P$, with most hamsters reaching or exceeding their original $L P$ body weight after only six weeks. The body weight increase reached a plateau phase after approximately 12 weeks and ten more weeks in LP had no further significant effect.

Previously it has been described that photorefractory hamsters that had completely regained their LP phenotype in continuous SP exposure for $>20$ weeks need at least ten weeks in LP to regain SP sensitivity (37-39). We initially hypothesized that only hamsters re-exposed after 14 weeks in LP $\left(\mathrm{SP}_{14} \mathrm{LP}_{14} \mathrm{SP}_{8}\right)$, but not after six weeks in $\mathrm{LP}\left(\mathrm{SP}_{14} \mathrm{LP}_{6} \mathrm{SP}_{8}\right)$, would be able to respond to a second $\mathrm{SP}$ reexposure. Surprisingly, hamsters re-exposed to SP after only six weeks in $\mathrm{LP}\left(\mathrm{SP}_{14} \mathrm{LP}_{6} \mathrm{SP}_{8}\right)$ responded to the photoperiodic signal as they all stopped gaining body weight. Therefore these data do not support our hypothesis for the requirement of an extended LP exposure but however, it is noticeable that weight loss was muted and only some animals started to reduce body weight once more (Supplementary Figure 1B). One explanation for this response may be that during the duration of 14 weeks of SP exposure (the trough of SP adaptations in body weight and reproduction), hamsters had not yet become photorefractory and some SP sensitivity remained or could be partially restored by only six weeks in LP.

In hamsters re-exposed to $\mathrm{LP}$ for 14 weeks before a further SP exposure $\left(\mathrm{SP}_{14} \mathrm{LP}_{14} \mathrm{SP}_{8}\right)$, a divergent body weight response seemed to be evident. As body weight can fluctuate on a daily basis with gains or losses in some photoperiod non-responsive hamsters, we applied criteria of SP responsiveness as a loss of body weight of $10 \%$ or greater from peak value after 7 weeks exposure to SP and to below the weight at the time transfer from LP to SP. Using these criteria the response of hamsters switched back to SP after 14 weeks in $\mathrm{LP}\left(\mathrm{SP}_{14} \mathrm{LP}_{14} \mathrm{SP}_{8}\right)$ was divided. Half of the hamsters responded with a more pronounced weight loss than hamsters re-exposed to SP after six weeks LP exposure

This article is protected by copyright. All rights reserved. 
$\left(\mathrm{SP}_{14} \mathrm{LP}_{6} \mathrm{SP}_{8}\right)$. The other half of the $\mathrm{SP}_{14} \mathrm{LP}_{14} \mathrm{SP}_{8}$ group did not respond to $\mathrm{SP}$ re-exposure. These hamsters were not non-responders per se, because they had shown a normal SP adaptation after the initial switch from LP to SP for 14 weeks $(26.2 \% \pm 6.6 \%$ body weight loss and a weight loss of $14 \%$ or greater within eight weeks of exposure to SP). Furthermore, this differential physiological response was also partially reflected in hypothalamic gene expression. However, hamsters can vary considerably in the rapidity of response to a change in photoperiod direction and this may be evident in our analysis where one non-responder may have been reclassified as responder given a longer duration in SP.

\section{Serum concentrations}

Total serum concentrations of $T_{4}$ and $T_{3}$ showed no significant differences in response to alternating photoperiods. Changes in thyroid hormone concentrations were highly variable between animals, which might have overridden potential differences caused by photoperiodic changes. Other studies were able to measure seasonal fluctuations in serum concentrations, but experimental setup and timing of sampling was different $(25,42)$. The diversity of different studies and high inter-individual variability in the current data suggest that serum thyroid hormone concentrations, at least in our stable laboratory conditions, are not directly involved in photoperiodic changes of physiology. Rather intracellular $\mathrm{T}_{3}$ levels, controlled by deiodinases, in specific tissues such as the hypothalamus seem to be regulating metabolism and body weight in a photoperiodic setting.

\section{Gene expression}

Most photoperiodic gene transcription changes were located in tanycytes of the ependymal layer of the third ventricle adjacent to the hypothalamus which are critically involved in seasonal adaptation of energy balance, metabolism and growth $(14,43)$. Djungarian hamsters exposed to SP showed lower expression of Vimentin in tanycytes, which has been demonstrated previously and is associated with structural changes of these cells $(8,16,17)$.

Thyroid hormone availability in the hypothalamus is regulated by deiodinases, which play a central role in seasonal adaptation $(18,19,21)$. The current view is that low Dio2 and high Dio3 expression during SP exposure lead to low $T_{3}$ concentrations in the hypothalamus, which is considered to be a pre-requisite for many of the adaptive responses to SP. On re-exposure to static LP or naturally lengthening days after the winter solstice, absent Dio3 expression and an induction of Dio2 expression contributes to re-establishing LP physiology in the hamster $(8,20,21,44)$.

In our study, ependymal Dio2 expression did not show a reduction after the initial 14 weeks in SP $\left(\mathrm{SP}_{14}\right)$ when body weight had maximally decreased. Furthermore, after a substantial increase in

This article is protected by copyright. All rights reserved. 
expression following six weeks of re-exposure to LP, by 14 weeks Dio2 started to decline and by 22 weeks had returned to values found in hamsters at $\mathrm{LP}_{0}$. A decline of Dio2 over a static constant $\mathrm{LP}$ has previously been noted (12), which together with a study analysing gene expression in natural photoperiod suggests, that Dio2 expression can become refractory to LP (44). Therefore, Dio2 at sample points $\mathrm{LP}_{0}$ and $\mathrm{SP}_{14}$ in our study likely reflects the nadir of a refractory Dio2 expression at the time the hamsters were sampled in each photoperiod.

The SP non-responsive hamsters following a 14 week re-exposure to $\mathrm{LP}\left(\mathrm{SP}_{14} \mathrm{LP}_{14} \mathrm{SP}_{8}\right)$ also had low Dio2 expression with the exception of one hamster whose body weight increased during eight weeks in SP (Figure 4A, B). These data suggest that although low tanycyte Dio2 expression is likely to be a pre-requisite for a sufficient reduction in hypothalamic $T_{3}$ availability, continual high levels of hypothalamic $T_{3}$ are not required to maintain LP body weight. This is consistent with our previous data obtained over the course of one year in natural photoperiod which showed that body weight continues to increase for four weeks or more after the summer solstice, even though Dio2 expression is reduced to near minimal expression by mid-July or earlier (44).

Importantly, Dio2 expression must always be interpreted in combination with Dio3 expression. In static photoperiods Djungarian hamsters show complete absence of Dio3 expression in LP and a transient expression in SP with highest levels of expression within about eight to ten weeks of SP exposure, which then becomes refractory and declines to low or absent levels in a continuing SP environment $(12,21,25,34)$. As a result, DIO3 in SP is likely to convert $T_{4}$ into $r T_{3}$, before it can be converted by $\mathrm{DIO} 2$ to $\mathrm{T}_{3}$, or DIO3 inactivates available $\mathrm{T}_{3}$ by conversion to $\mathrm{T}_{2}$. Given similar Dio2 expression levels in $\mathrm{LP}_{0}$ and $\mathrm{SP}_{14}$, the data suggest that the key event in physiological $\mathrm{SP}$ responsiveness is expression of Dio3. Consistent with this notion, Dio3 only responded weakly overall after exposure to $\mathrm{SP}$ following a six week re-exposure to $\mathrm{LP}\left(\mathrm{SP}_{14} \mathrm{LP}_{6} \mathrm{SP}_{8}\right)$, when body weight loss was low. After a 14 week re-exposure to LP, a subsequent re-exposure to SP Dio3 strongly increased in responsive hamsters, and with one exception, was low in non-responders $\left(\mathrm{SP}_{14} \mathrm{LP}_{14} \mathrm{SP}_{8}\right.$, Figure 4B). The hamster with an exception in Dio3 expression levels in the group of non-responders may however, be a late responsive hamster. Body weight of this hamster continued to increase for six weeks after re-exposure to SP and then decreased in the next two weeks before the hamster was culled, but had not reached a weight loss relative to the time of transition from LP to SP (Figure 4A). Had this hamster spent further time in SP, it may have become evident that this hamster was a responder. Taken together, the photoperiodic history i.e. the length of exposure to LP after the first re-exposure from SP may have an impact on the intensity of Dio3 expression response which is also reflected in the body weight change and has been previously discussed (45).

This article is protected by copyright. All rights reserved. 
However, Mct8 expression also needs to be considered in the context of thyroid hormone availability. The function of Mct8 in the photoperiod response is not known, but as a bidirectional T4/T3 transporter (46), one possibility is that an increase in Mct8 in SP could function to facilitate removal of $T_{4}$ and $T_{3}$ from the hypothalamus to aid reduction in $T_{3}$ availability. Similar to Dio3, in the context of responsiveness to SP, those hamsters which responded to SP showed higher expression levels of Mct8, whereas in SP non-responsive hamsters Mct8 expression was not significantly increased relative to those in LP at 22 weeks. There is the possibility that other thyroid hormone transporters may have a role to play, but to date OATP1c has not been found in the ependymal layer of the Djungaian hamster and MCT10 has to our knowledge not been examined (47). Nevertheless, our data indicate that an appropriate co-ordinated response of all components of the thyroid hormone metabolism/transport system is likely to be required for successful initiation of SP physiology.

Photoperiod regulated Tsh-r expression in the ependymal layer is a possible factor in the transmission of the day length signal provided by a duration dependent melatonin-signal transduction pathway, to a genomic and physiological action. In contrast to a previous study, which showed a lower expression during SP, we found no differences in Tsh-r mRNA expression between LP and SP (8). Our results suggest that altered Tsh-r expression does not play a critical role in mediating seasonal physiology.

Somatostatin expression in the ARC has been shown to be substantially increased upon exposure to SP and has been proposed to be involved in suppressing the growth hormone axis, hence may be a key player in seasonal body weight regulation $(33,34)$. Furthermore, evidence obtained from in vivo TSH administration studies suggests Srif expression is downstream of thyroid signalling in the hypothalamus (48). In accordance with other studies, Srif was highly expressed in SP and reduced to minimal expression when hamsters were switched from SP to $L P\left(\mathrm{SP}_{14} \mathrm{LP}_{6}\right)$. After re-exposure to $\mathrm{SP}$ from LP, Srif expression only achieved $36 \%\left(\mathrm{SP}_{14} \mathrm{LP}_{6} \mathrm{SP}_{8}\right)$ and $60 \%\left(\mathrm{SP}_{14} \mathrm{LP}_{14} \mathrm{SP}_{8}\right.$ responsive hamsters), respectively compared to $\mathrm{SP}_{14}$. This is consistent with the hypothesis for an involvement of ARC Srif in the growth hormone axis and the lower expression achieved in the $\mathrm{SP}_{14} \mathrm{LP}_{6} \mathrm{SP}_{8}$ group may at least in part account for the smaller body weight loss achieved by this group. Also consistent is that hamsters which were SP non-responsive after 14 weeks of $\mathrm{LP}$ re-exposure $\left(\mathrm{SP}_{14} \mathrm{LP}_{14} \mathrm{SP}_{8}\right.$ constant body weight) showed a low level of expression that was comparable to their $L P$ counterparts $\left(\mathrm{SP}_{14} \mathrm{LP}_{22}\right)$. In accordance with previous studies Gpr50 was down regulated during SP in Djungarian hamsters $\left(\mathrm{SP}_{14}\right)(8,26)$. Gene expression of Gpr50 in the ependymal layer was reversed after re-exposure to LP from $\mathrm{SP}\left(\mathrm{SP}_{14} \mathrm{LP}_{6}\right)$. However, the increase was retarded and restoration of $L P_{0} m R N A$ concentrations was not reached after six weeks, but only after 14 weeks $\left(\mathrm{SP}_{14} \mathrm{LP}_{14}\right)$ re-exposure to $\mathrm{LP}$. The function

This article is protected by copyright. All rights reserved. 
of GPR50 in seasonal adaptations is not understood, but a recent study in mice has shown that knock-out of GPR50 results in a higher level of expression of Dio2 in tanycytes (49). In the context of the Djungarian hamster a similar mechanism offers an explanation for a reduction in Dio2 upon reexposure to LP for 14 weeks or more, where there is an inverse relationship between Dio2 and Gpr50 expression. Furthermore in natural photoperiod Gpr50 expression only starts to increase at around the time Dio2 has almost reached a nadir of expression and peaks around the autumnal equinox (44). However, contradicting this explanation is the observed reduction in Dio2, but little change of $G p r 50$ in non-responsive hamsters of the $\mathrm{SP}_{14} \mathrm{LP}_{14} \mathrm{SP}_{8}$ group.

Expression of Crbp1 in the ependymal layer was regulated by photoperiod in a similar manner to the expression of Gpr50. CRBP1 is responsible for the intracellular transport of retinol, the substrate for the synthesis of retinoic acid (50) and was, together with other retinoid-signalling genes, discovered as photoperiod-responsive (28). Re-exposure of hamsters from SP to $L P$ (groups $\mathrm{SP}_{14} \mathrm{LP}_{6}$ and $\mathrm{CP}_{14} \mathrm{LP}_{14}$ ) induced a slow reversion of Crbp1 gene expression, which has been observed in a previous study (28). Crbp1 responded again to the second switch from LP to SP after six $\left(\mathrm{SP}_{14} \mathrm{LP}_{6} \mathrm{SP}_{8}\right)$ and 14 weeks $\left(\mathrm{SP}_{14} \mathrm{LP}_{14} \mathrm{SP}_{8}\right)$ in $\mathrm{LP}$, but only in the responsive hamsters of this latter group. Ross and colleagues (28) have shown, that in photorefractory hamsters body weight increased, but Crbp1 expression remained low. Together with our results, this suggests that Crbp1 was regulated by the photoperiodic signal, but only played a minor role in seasonal body weight regulation. Nonetheless the retinoid-signalling pathway is under photoperiod control, but the function of Crbp1 gene expression remains unclear.

Taken together all results from non-responding hamsters demonstrate that these animals were insensitive to the SP signal which was largely reflected in gene expression profiles. Why some animals responded to the second photoperiodic switch after 14 weeks, and others did not, remains to be investigated. However, the gene expression data of the non-responding hamsters would suggest a continuation of a LP output of the PT in these SP non-responsive hamsters.

In summary, our data provide additional support for an involvement of a co-ordinated response of the thyroid hormone metabolism/transport system, and other photoperiodically regulated genes in seasonal physiological adaptations. Additionally, Dio2 expression in response to LP re-exposure supports a previous suggestion that this gene may become refractory to LP; a response which has only be described in the long lived seasonal sheep.

\section{Acknowledgements}

This work was funded by the German Research Foundation (DFG, Emmy-Noether HE6383 to AH) and the British Society for Neuroendocrinology (Research grant to JB).

This article is protected by copyright. All rights reserved. 


\section{Conflict of interest}

The authors declare that they have no conflict of interest.

\section{References}

1. Figala J, Hoffmann, K, Goldau, G. Zur Jahresperiodik beim Dsungarischen Zwerghamster Phodopus sungorus Pallas. Oecologia. 1973; 1389-118.

2. Bartness TJ, Elliott JA, Goldman BD. Control of torpor and body weight patterns by a seasonal timer in Siberian hamsters. The American journal of physiology. 1989; 257(1 Pt 2): R142-9.

3. Morgan PJ, Mercer JG. The regulation of body weight: lessons from the seasonal animal. The Proceedings of the Nutrition Society. 2001; 60(1): 127-34.

4. Steinlechner S, Heldmaier, G, Becker, H. The seasonal cycle of body weight in the Siberian hamster: photoperiodic control and the influence of starvation and melatonin. Oecologia. 1983; 60401-5.

5. Steinlechner S, Heldmaier G. Role of photoperiod and melatonin in seasonal acclimatization of the Djungarian hamster, Phodopus sungorus. International journal of biometeorology. 1982; 26(4): 329-37.

6. Vitale PM, Darrow JM, Duncan MJ, Shustak CA, Goldman BD. Effects of photoperiod, pinealectomy and castration on body weight and daily torpor in Djungarian hamsters (Phodopus sungorus). The Journal of endocrinology. 1985; 106(3): 367-75.

7. Illnerova $\mathrm{H}$, Hoffmann $\mathrm{K}$, Vanecek J. Adjustment of pineal melatonin and $\mathrm{N}$-acetyltransferase rhythms to change from long to short photoperiod in the Djungarian hamster Phodopus sungorus. Neuroendocrinology. 1984; 38(3): 226-31.

8. Herwig A, de Vries EM, Bolborea M, Wilson D, Mercer JG, Ebling FJ, Morgan PJ, Barrett P. Hypothalamic ventricular ependymal thyroid hormone deiodinases are an important element of circannual timing in the Siberian hamster (Phodopus sungorus). PloS one. 2013; 8(4): e62003.

9. Hoffmann K. Effects of short photoperiods on puberty, growth and moult in the Djungarian hamster (Phodopus sungorus). Journal of reproduction and fertility. 1978; 54(1): 29-35.

10. Niklowitz P, De Geyter M, Schlatt S, Hoffmann K, Nieschlag E. Pattern of pineal melatonin concentrations during prolonged exposure to short photoperiods in photosensitive and photoinsensitive Djungarian hamsters. Journal of pineal research. 1992; 12(2): 64-70.

11. Schlatt S, De Geyter M, Kliesch S, Nieschlag E, Bergmann M. Spontaneous recrudescence of spermatogenesis in the photoinhibited male Djungarian hamster, Phodopus sungorus. Biology of reproduction. 1995; 53(5): 1169-77.

12. Watanabe T, Yamamura T, Watanabe M, Yasuo S, Nakao N, Dawson A, Ebihara S, Yoshimura T. Hypothalamic expression of thyroid hormone-activating and -inactivating enzyme genes in relation to photorefractoriness in birds and mammals. American journal of physiology Regulatory, integrative and comparative physiology. 2007; 292(1): R568-72.

13. Prendergast BJ, Mosinger B, Jr., Kolattukudy PE, Nelson RJ. Hypothalamic gene expression in reproductively photoresponsive and photorefractory Siberian hamsters. Proceedings of the National Academy of Sciences of the United States of America. 2002; 99(25): 16291-6.

14. Bolborea M, Dale N. Hypothalamic tanycytes: potential roles in the control of feeding and energy balance. Trends in neurosciences. 2013; 36(2): 91-100.

15. Rodriguez EM, Blazquez JL, Pastor FE, Pelaez B, Pena P, Peruzzo B, Amat P. Hypothalamic tanycytes: a key component of brain-endocrine interaction. International review of cytology. 2005; 24789-164.

This article is protected by copyright. All rights reserved. 
16. Bolborea M, Laran-Chich MP, Rasri K, Hildebrandt H, Govitrapong P, Simonneaux V, Pevet P, Steinlechner S, Klosen P. Melatonin controls photoperiodic changes in tanycyte vimentin and neural cell adhesion molecule expression in the Djungarian hamster (Phodopus sungorus). Endocrinology. 2011; 152(10): 3871-83.

17. Kameda $Y$, Arai $Y$, Nishimaki T. Ultrastructural localization of vimentin immunoreactivity and gene expression in tanycytes and their alterations in hamsters kept under different photoperiods. Cell and tissue research. 2003; 314(2): 251-62.

18. Hanon EA, Lincoln GA, Fustin JM, Dardente $H$, Masson-Pevet M, Morgan PJ, Hazlerigg DG. Ancestral TSH mechanism signals summer in a photoperiodic mammal. Current biology : CB. 2008; 18(15): 1147-52.

19. Nakao N, Ono H, Yamamura T, Anraku T, Takagi T, Higashi K, Yasuo S, Katou Y, Kageyama S, Uno Y, Kasukawa T, ligo M, Sharp PJ, Iwasawa A, Suzuki Y, Sugano S, Niimi T, Mizutani M, Namikawa $T$, Ebihara S, Ueda HR, Yoshimura T. Thyrotrophin in the pars tuberalis triggers photoperiodic response. Nature. 2008; 452(7185): 317-22.

20. Murphy M, Jethwa PH, Warner A, Barrett P, Nilaweera KN, Brameld JM, Ebling FJ. Effects of manipulating hypothalamic triiodothyronine concentrations on seasonal body weight and torpor cycles in Siberian hamsters. Endocrinology. 2012; 153(1): 101-12.

21. Barrett $P$, Ebling FJ, Schuhler S, Wilson D, Ross AW, Warner A, Jethwa P, Boelen A, Visser TJ, Ozanne DM, Archer ZA, Mercer JG, Morgan PJ. Hypothalamic thyroid hormone catabolism acts as a gatekeeper for the seasonal control of body weight and reproduction. Endocrinology. 2007; 148(8): 3608-17.

22. Friesema EC, Ganguly S, Abdalla A, Manning Fox JE, Halestrap AP, Visser TJ. Identification of monocarboxylate transporter 8 as a specific thyroid hormone transporter. The Journal of biological chemistry. 2003; 278(41): 40128-35.

23. Herwig A, Campbell G, Mayer CD, Boelen A, Anderson RA, Ross AW, Mercer JG, Barrett P. A thyroid hormone challenge in hypothyroid rats identifies $\mathrm{T} 3$ regulated genes in the hypothalamus and in models with altered energy balance and glucose homeostasis. Thyroid : official journal of the American Thyroid Association. 2014; 24(11): 1575-93.

24. Kohrle J. Local activation and inactivation of thyroid hormones: the deiodinase family. Molecular and cellular endocrinology. 1999; 151(1-2): 103-19.

25. Herwig A, Wilson D, Logie TJ, Boelen A, Morgan PJ, Mercer JG, Barrett P. Photoperiod and acute energy deficits interact on components of the thyroid hormone system in hypothalamic tanycytes of the Siberian hamster. American journal of physiology Regulatory, integrative and comparative physiology. 2009; 296(5): R1307-15.

26. Barrett P, Ivanova E, Graham ES, Ross AW, Wilson D, Ple H, Mercer JG, Ebling FJ, Schuhler S, Dupre SM, Loudon A, Morgan PJ. Photoperiodic regulation of cellular retinol binding protein, CRBP1 [corrected] and nestin in tanycytes of the third ventricle ependymal layer of the Siberian hamster. The Journal of endocrinology. 2006; 191(3): 687-98.

27. Helfer G, Ross AW, Russell L, Thomson LM, Shearer KD, Goodman TH, McCaffery PJ, Morgan PJ. Photoperiod regulates vitamin A and Wnt/beta-catenin signaling in F344 rats. Endocrinology. 2012; 153(2): 815-24.

28. Ross AW, Webster CA, Mercer JG, Moar KM, Ebling FJ, Schuhler S, Barrett P, Morgan PJ. Photoperiodic regulation of hypothalamic retinoid signaling: association of retinoid $\mathrm{X}$ receptor gamma with body weight. Endocrinology. 2004; 145(1): 13-20.

29. Lane MA, Bailey SJ. Role of retinoid signalling in the adult brain. Progress in neurobiology. 2005; 75(4): 275-93.

30. Drew JE, Barrett P, Williams LM, Conway S, Morgan PJ. The ovine melatonin-related receptor: cloning and preliminary distribution and binding studies. Journal of neuroendocrinology. 1998; 10(9): 651-61.

31. Reppert SM, Weaver DR, Ebisawa T, Mahle CD, Kolakowski LF, Jr. Cloning of a melatoninrelated receptor from human pituitary. FEBS letters. 1996; 386(2-3): 219-24.

This article is protected by copyright. All rights reserved. 
32. Brazeau P, Vale W, Burgus R, Ling N, Butcher M, Rivier J, Guillemin R. Hypothalamic polypeptide that inhibits the secretion of immunoreactive pituitary growth hormone. Science. 1973; 179(4068): 77-9.

33. Dumbell RA, Scherbarth F, Diedrich V, Schmid HA, Steinlechner S, Barrett P. Somatostatin Agonist Pasireotide Promotes a Physiological State Resembling Short-Day Acclimation in the Photoperiodic Male Siberian Hamster (Phodopus sungorus). Journal of neuroendocrinology. 2015; 27(7): 588-99.

34. Herwig A, Petri I, Barrett P. Hypothalamic gene expression rapidly changes in response to photoperiod in juvenile Siberian hamsters (Phodopus sungorus). Journal of neuroendocrinology. 2012; 24(7): 991-8.

35. Ross AW, Bell LM, Littlewood PA, Mercer JG, Barrett P, Morgan PJ. Temporal changes in gene expression in the arcuate nucleus precede seasonal responses in adiposity and reproduction. Endocrinology. 2005; 146(4): 1940-7.

36. Yellon SM, Goldman BD. Photoperiod control of reproductive development in the male Djungarian hamster (Phodopus sungorus). Endocrinology. 1984; 114(2): 664-70.

37. Bittman EL. Photoperiodic influences on testicular regression in the golden hamster: termination of scotorefractoriness. Biology of reproduction. 1978; 18(5): 871-7.

38. Kauffman AS, Freeman DA, Zucker I. Termination of neuroendocrine refractoriness to melatonin in Siberian hamsters (Phodopus sungorus). Journal of neuroendocrinology. 2003; 15(2): 191-6.

39. Reiter RJ. Evidence for refractoriness of the pituitary-gonadal axis to the pineal gland in golden hamsters and its possible implications in annual reproductive rhythms. The Anatomical record. 1972; 173(3): 365-71.

40. Bank JH, Kemmling J, Rijntjes E, Wirth EK, Herwig A. Thyroid hormone status affects expression of daily torpor and gene transcription in Djungarian hamsters (Phodopus sungorus). Hormones and behavior. 2015; 75120-9.

41. Ross AW, Johnson CE, Bell LM, Reilly L, Duncan JS, Barrett P, Heideman PD, Morgan PJ. Divergent regulation of hypothalamic neuropeptide $Y$ and agouti-related protein by photoperiod in F344 rats with differential food intake and growth. Journal of neuroendocrinology. 2009; 21(7): 6109.

42. Seidel A, Heldmaier G, Schulz F. Seasonal changes in circulating levels of thyroid hormones are not dependent on the age in Djungarian hamsters Phodopus sungorus. Comparative biochemistry and physiology A, Comparative physiology. 1987; 88(1): 71-3.

43. Ebling FJ. Hypothalamic control of seasonal changes in food intake and body weight. Frontiers in neuroendocrinology. 2015; 3797-107.

44. Petri I, Diedrich, V., Wilson, D., Fernandez-Calleja, J., Herwig, A., Steinlechner, S., Barrett, P. Orchestration of gene expression across the seasons: Hypothalamic gene expression in natural photoperiod throughout the year in the Siberian hamster. Scientific Reports. 2016; 6(29689).

45. Stevenson TJ, Prendergast BJ. Reversible DNA methylation regulates seasonal photoperiodic time measurement. Proceedings of the National Academy of Sciences of the United States of America. 2013; 110(41): 16651-6.

46. Visser WE, Friesema EC, Jansen J, Visser TJ. Thyroid hormone transport in and out of cells. Trends in endocrinology and metabolism: TEM. 2008; 19(2): 50-6.

47. Bank JH, Cubuk C, Wilson D, Rijntjes E, Kemmling J, Markovsky H, Barrett P, Herwig A. Gene expression analysis and microdialysis suggest hypothalamic triiodothyronine (T3) gates daily torpor in Djungarian hamsters (Phodopus sungorus). J Comp Physiol B. 2017.

48. Klosen P, Sebert ME, Rasri K, Laran-Chich MP, Simonneaux V. TSH restores a summer phenotype in photoinhibited mammals via the RF-amides RFRP3 and kisspeptin. FASEB journal : official publication of the Federation of American Societies for Experimental Biology. 2013; 27(7): 2677-86.

This article is protected by copyright. All rights reserved. 
49. Bechtold DA, Sidibe A, Saer BR, Li J, Hand LE, Ivanova EA, Darras VM, Dam J, Jockers R, Luckman SM, Loudon AS. A role for the melatonin-related receptor GPR50 in leptin signaling, adaptive thermogenesis, and torpor. Current biology : CB. 2012; 22(1): 70-7.

50. Li E, Norris AW. Structure/function of cytoplasmic vitamin A-binding proteins. Annual review of nutrition. 1996; 16205-34.

\section{Figure legends}

Figure 1: Experimental schedule. Hamsters were kept under long photoperiod LP or short photoperiod (SP) and euthanized at different time points.

Figure 2: Body weight changes of all animals $(A)$ and absolute body weights of the distinct groups (B) are expressed as means ( $\mathbf{S E M}$ ). Animals were kept under short photoperiod (SP, white circle) or long photoperiod (LP, black circle). One cohort was sacrificed at time point $A\left(S_{14}\right)$, one cohort at $B$ $\left(\mathrm{SP}_{14} \mathrm{LP} \mathrm{P}_{6}\right)$, two cohorts at $\mathrm{C}\left(\mathrm{SP}_{14} \mathrm{LP}_{14}, \mathrm{SP}_{14} \mathrm{LP}_{6} \mathrm{SP}_{8}\right)$ and two cohorts at $\mathrm{D}\left(\mathrm{SP}_{14} \mathrm{LP}_{22}, \mathrm{SP}_{14} \mathrm{LP}_{14} \mathrm{SP}_{8}\right)$. The $\mathrm{SP}_{14} \mathrm{LP}_{14} \mathrm{SP}_{8}$ (D) group was divided into hamsters which lost weight (white circle) and hamsters with constant body weight (grey circle).

Figure 2: Dio2 (A) and Dio3 (B) gene expression in ventricular ependymal cells of all groups. Data are expressed as means + SEM. Integrated optical intensity (IOD) was normalized to SP 14 . Black bars represent hamsters culled in long photoperiod (LP), white bars illustrate hamsters from short photoperiod (SP) and the grey bar shows non-responsive animals from SP. White bar at $\mathrm{SP}_{14} \mathrm{LP}_{14}$ represents group $\mathrm{SP}_{14} \mathrm{LP}_{6} \mathrm{SP}_{8}$ and at $\mathrm{SP}_{14} \mathrm{LP}_{22}$ it represents group $\mathrm{SP}_{14} \mathrm{LP}_{14} \mathrm{SP}_{8}$. The grey bar represents hamsters from the $\mathrm{SP}_{14} \mathrm{LP}_{14} \mathrm{SP}_{8}$ group that did not reduce body weight. ${ }^{*}$ significant difference to $\mathrm{SP}_{14}$; significant difference between other groups. Autoradiographs show representative brain sections with gene expression close to mean values.

Figure 4: Individual body weight changes (C) and individual Dio2 and Dio3 expression values (D) of $\mathbf{S P}_{14} \mathrm{LD}_{14} \mathbf{S P}_{8}$ hamsters. Data are presented relative to the peak body weight of each individual. White symbols represent SP responsive hamsters losing body weight, grey symbols represent SP nonresponsive hamsters maintaining stable body weight.

Figure 5: Gene expression Mct8 (A), Vimentin (B), Gpr50 (C), Crbp1 (D) in ventricular ependymal cells and Srif (E) in the arcuate nucleus. Data are expressed as means + SEM. Integrated optical intensity (IOD) was normalized to $\mathrm{SP}_{14}$ for genes downregulated in $L P(A, E)$ or $L_{0}$ for genes upregulated in LP (B-D). Black bars represent hamsters culled in long photoperiod (LP), white bars

This article is protected by copyright. All rights reserved. 
illustrate hamsters from short photoperiod (SP) and the grey bar shows non-responsive animals from SP. White bar at $S P_{14} L_{14}$ represents group $S P_{14} L P_{6} S P_{8}$ and at $S_{14} L P_{22}$ it represents group $\mathrm{SP}_{14} \mathrm{LP}_{14} \mathrm{SP}_{8}$. The grey bar represents hamsters from the $\mathrm{SP}_{14} \mathrm{LP}_{14} \mathrm{SP}_{8}$ group that did not reduce body weight. * significant difference to $\mathrm{SP}_{14} ;{ }^{\#}$ significant difference between other groups. Autoradiographs show representative brain sections with gene expression close to mean values.

\section{Tables}

Table 1: Serum concentrations (mean $\pm \mathrm{SEM}$ ) of total $\mathrm{T}_{4}$ and total $\mathrm{T}_{3}$.

Supplementary Figure 1: Individual body weight changes of hamsters from the $\mathrm{SP}_{14}$ group exposed to short photoperiod (SP) for the first time (A) and from the $\mathbf{S P}_{14} \mathbf{L P}_{6} \mathbf{S P}_{8}$ group exposed to $S P$ the second time after six weeks re-exposure to long photoperiod (LP) (B). Data are presented relative to the peak body weight of each individual.

\begin{tabular}{|l|l|l|l|l|l|l|l|}
\hline & $\mathrm{LP}_{0}$ & $\mathrm{SP}_{14}$ & $\mathrm{SP}_{14} \mathrm{LP}_{6}$ & $\mathrm{SP}_{14} \mathrm{LP}_{14}$ & $\mathrm{SP}_{14} \mathrm{LP}_{6} \mathrm{SP}_{8}$ & $\mathrm{SP}_{14} \mathrm{LP}_{22}$ & $\mathrm{SP}_{14} \mathrm{LP}_{14} \mathrm{SP}_{8}$ \\
\hline Group size & $\mathrm{n}=6$ & $\mathrm{n}=5$ & $\mathrm{n}=6$ & $\mathrm{n}=6$ & $\mathrm{n}=6$ & $\mathrm{n}=11$ & $\mathrm{n}=11$ \\
\hline Total $\mathrm{T}_{4}(\mathrm{nM})$ & $50 \pm 3$ & $42 \pm 6$ & $63 \pm 6$ & $55 \pm 2$ & $57 \pm 2$ & $44 \pm 2$ & $53 \pm 14$ \\
\hline Total $\mathrm{T}_{3}(\mathrm{nM})$ & $1.8 \pm 0.1$ & $1.8 \pm 0.2$ & $1.9 \pm 0.1$ & $1.7 \pm 0.1$ & $1.7 \pm 0.1$ & $1.8 \pm 0.1$ & $2.0 \pm 0.4$ \\
\hline
\end{tabular}

\begin{tabular}{|c|c|c|c|c|c|}
\hline Group & $\mathrm{N}$ & & & & \\
\hline $\mathrm{LP}_{0}$ & 6 & LP & & & \\
\hline $\mathrm{SP}_{14}$ & 6 & LP & 14 weeks SP & & \\
\hline $\mathrm{SP}_{14} \mathrm{LP}_{6}$ & 6 & $\mathbf{L P}$ & 14 weeks SP & 6 weeks LP & \\
\hline $\mathrm{SP}_{14} \mathrm{LP}_{14}$ & 6 & $\mathbf{L P}$ & 14 weeks SP & 14 weeks LP & \\
\hline $\mathrm{SP}_{14} \mathrm{LP}_{6} \mathrm{SP}_{8}$ & 6 & $\mathbf{L P}$ & 14 weeks SP & 8 weeks SP & \\
\hline $\mathrm{SP}_{14} \mathrm{LP}_{22}$ & 11 & LP & 14 weeks SP & 22 weeks LP & \\
\hline $\mathrm{SP}_{14} \mathrm{LP}_{14} \mathrm{SP}_{8}$ & 11 & LP & 14 weeks SP & 14 weeks LP & 8 weeks SP \\
\hline
\end{tabular}

This article is protected by copyright. All rights reserved. 

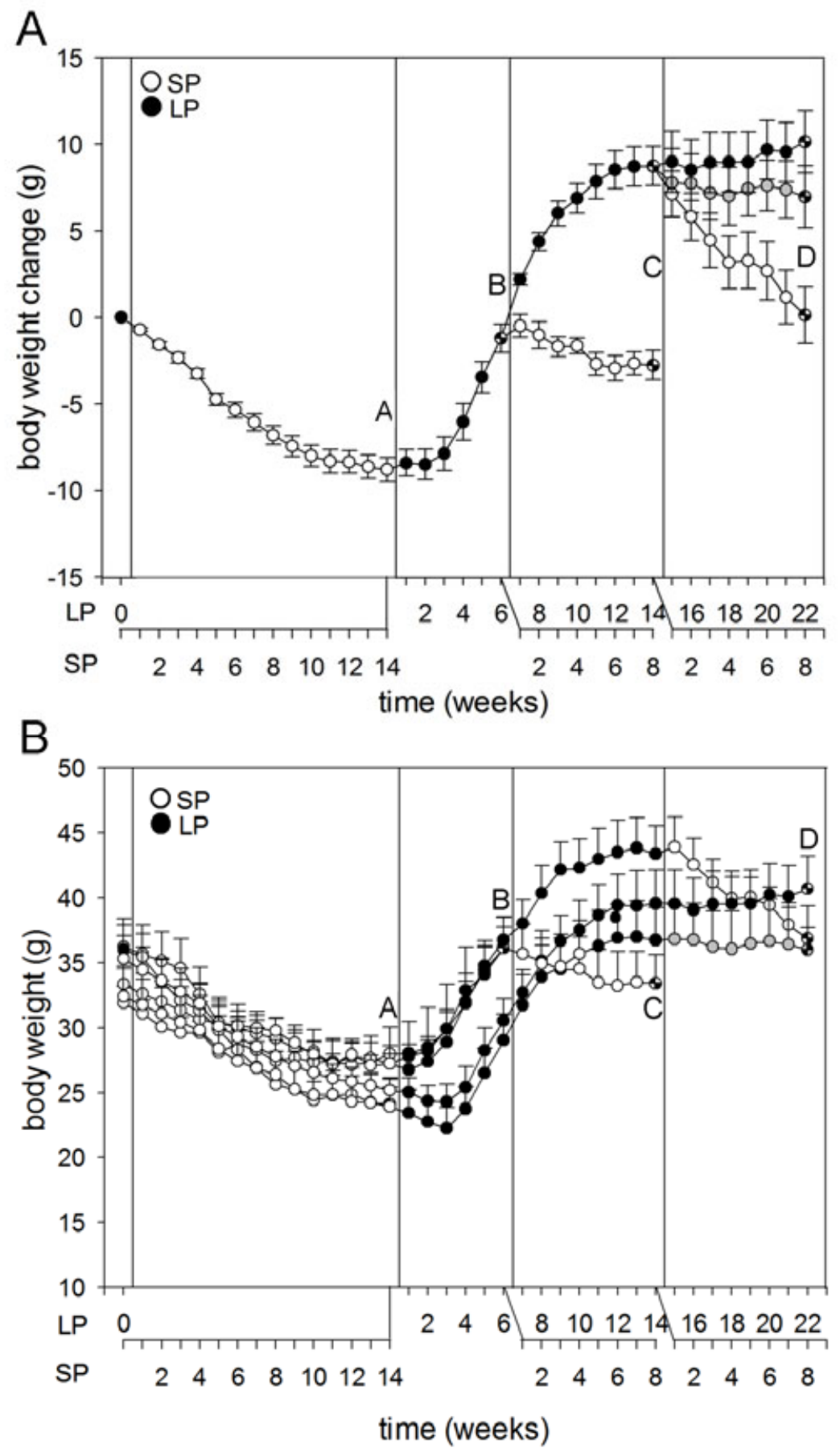

This article is protected by copyright. All rights reserved. 

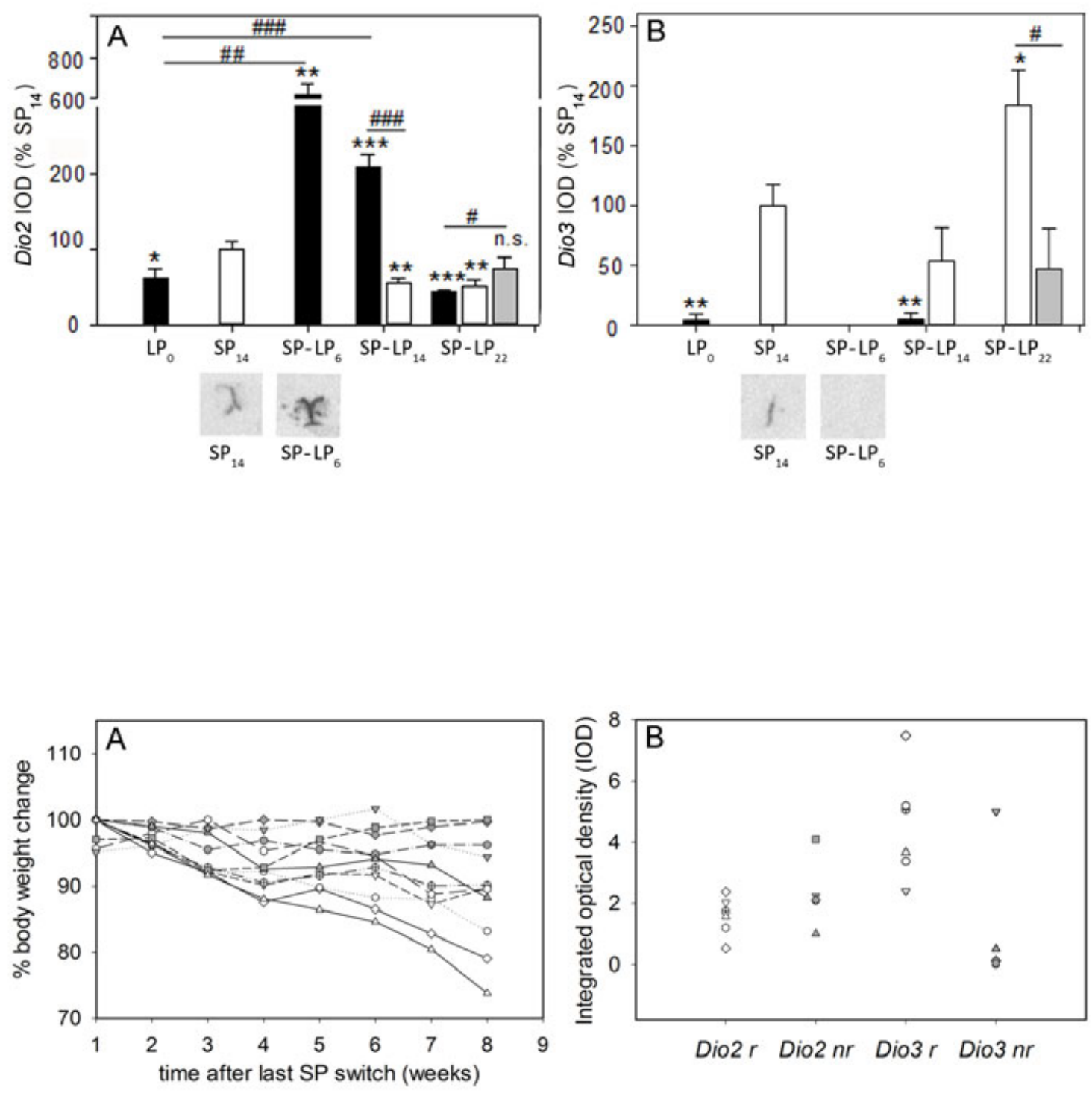

This article is protected by copyright. All rights reserved. 

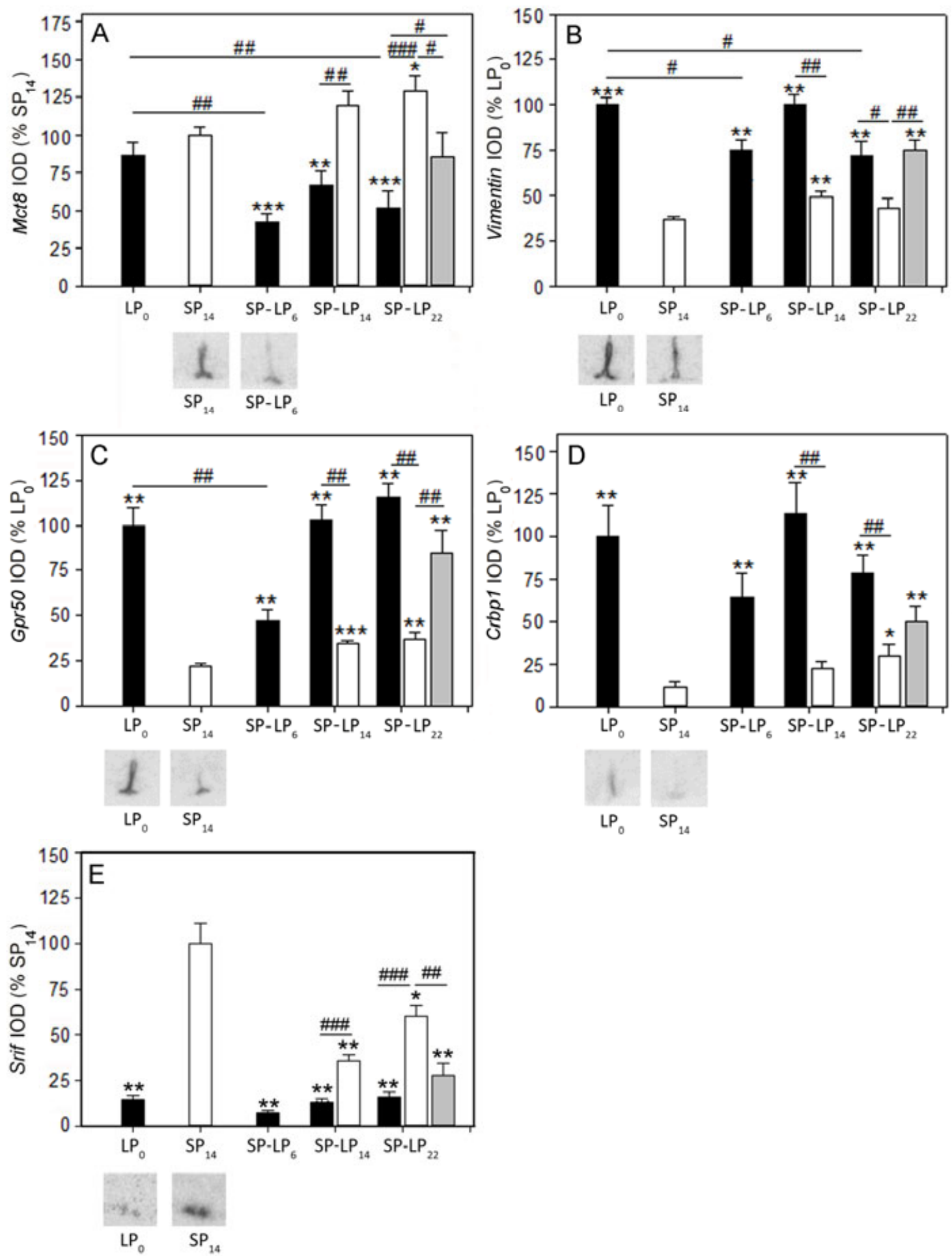

$L P_{0} \quad \mathrm{SP}_{14}$

This article is protected by copyright. All rights reserved. 